\title{
Absence and Desire in Michelangelo's Poetry: Literary Tradition and the Lesson(s) of the Manuscript
}

Gregory L. Lucente

In an essay published in 1983, "Lyric Tradition and the Desires of Absence: Rudel, Dante, and Michelangelo," I discussed the play of absence and desire in Michelangelo's poetry with special reference to the sonnet "Vorrei voler, Signor, quel ch'io non voglio" (Girardi 87; Frey 140). ${ }^{1}$ The aim of that essay was twofold: first, to come to terms with Michelangelo's general concept of the absence of the poet's beloved as a spur to literary creation, and, second, to situate that concept in an historical line that included both the Provençal poets and the dolce stil nuovo. With these ends in mind, I began by focusing on the poetry of Jaufré Rudel (for his strong association of desire with absence in the motif of the "amor lointain") and on that of Dante (for his Christian reinterpretation of this theme in the Vita nuova and the Rime), in order to gauge the crucial shift that occurred subsequently in Italian Renaissance lyric in regard to the internal force of the individual poet's desire and will.

In the course of my reading of Michelangelo's sonnet, in which religious confession blends with the tradition of the love lyric, I could not avoid commenting on the seemingly odd forms of the possessive adjectives, and I remarked that these forms reinforce the topic of gender confusion that is central to "Vorrei voler" as well as to so many of Michelangelo's other poems. Following are the tercets in which these forms occur, as Girardi gives them: 
Squarcia 'l vel tu, Signor, rompi quel muro

che con la suo durezza ne ritarda

il sol della tuo luce, al mondo spenta!

Manda 'l preditto lume, a noi venturo,

alla tuo bella sposa, accio ch'io arda

il cor senz'alcun dubbio, e te sol senta. (My italics)

After examining Michelangelo's autographs more closely, however, I have come to the conclusion that the real import of these adjectival forms lies elsewhere. As Giovanni Nencioni pointed out in an essay published in 1965 (the only instance in which an explanation for Michelangelo's use of the forms has been offered, rather than merely an expression of wonderment or of consternation), these forms are a part of an early Tuscan system of adjectival agreements. ${ }^{2}$ The system itself, as described by Nencioni, involves first-, second-, and third-person individual possessive adjectives in both singular and plural forms. The forms for both genders and both numbers preceding the noun are: mie, tuo, and suo. I should add that since Nencioni is discussing Michelangelo's letters as well as poetry, he also gives what he considers Michelangelo's characteristic plural forms following the noun (mia, tua, and sua). However, plurals following the noun are so rare in Michelangelo's poetry that no system for them can actually be substantiated in his verse, and singular forms following the noun are not uniform. At any rate, the results as they regard the forms preceding the noun are strikingly different from the standard Bembesque forms of contemporary sixteenth-century Italian. Some examples from Michelangelo's poetry: “mie mortal soccorso" (157), "la mie cara giornata" (58), "mie danni" (43), "le mie vecchie [piaghe]" (175); "tuo bel volto" (7), "la tuo clemenza" (289), "tuo primi sguardi" (114), "le tuo promesse" (23); "suo primo scoglio" (90), "suo vista serena" (35), “di suo gradi o lode" (109), "le suo cose eccelse" (9).

Again, even though these forms may seem strange at first glance, they do follow a system. However, this system-that is, the full system as opposed to mere remnants of it, such as the "mie" found so often in Tuscan writings-was not in common written use in Michelangelo's time. Moreover, Michelangelo himself uses it only in his verse, not in his letters or in his other writings, be they the humblest ricordi or the most elevated examples of his correspondence. Although these forms tend to lose the initial effect of their 
strangeness as one reads through Michelangelo's canzoniere, they must have created a certain degree of annoyance for the succeeding generations of his early copyists and editors, since in the copies the forms were usually normalized into the standard Bembesque ones. Interestingly enough, this process of editorial correction had begun even during Michelangelo's lifetime, as is evident in the manuscripts contained both in the Vatican Library in Rome and in the Laurentian Library in Florence (which include the great bulk of the surviving autographs).

The effects of this editorial "correction" initially caught my eye when, on reading first Frey's and then Girardi's editions of the Rime, I noticed that in a good number of instances the system of forms outlined by Nencioni is not followed. It is in fact true, as Nencioni notes, that Michelangelo did not adhere to this system in all cases. But again, once the original manuscripts have been consulted, it becomes clear that the vast majority of the divergences from Michelangelo's characteristic forms are due not to Michelangelo himself but to his editors and copisti. When we have genuine autographs of the poems, the system is followed, and followed with very few exceptions indeed. When we only possess copies, be they made for the projected (but never published) edition of the 1540 s or for other reasons, the forms tend to be normalized into the standard masculine and feminine endings. On occasion, we have versions of the poems written out by copisti in which the standard Bembesque forms are followed in the body of the text but with interlinear or marginal corrections in Michelangelo's hand in which he uses his own characteristic forms, thereby "correcting" the forms of his "correctors." In one instance (Vatican, Codice Latino 3211, f. 59 b; Girardi 245), Michelangelo even seems to correct himself when at the bottom of a page he includes two variants for a poem's last line, writing first his otherwise usual-but not poetic_ "tu $a$ mercede" and then correcting himself by immediately reverting in the second variant to his regular poetic form "tuo mercede." Finally, it is of interest, given our topic, that versions of the poems that were published in Michelangelo's time (including those treated by Benedetto Varchi in his Florentine Academy lectures, the sonnets in Dionigi Atanagi's 1565 collection of Tuscan verse, those included by Giorgio Vasari in his Vita and especially those in the second edition of 1568 shortly 
after Michelangelo's death, the sonnet on Dante published by Donato Giannotti in his Dialogi, and others) also demonstrate this process of editorial normalization.

Of all the editorial interventions to which Michelangelo's poetry was subject, the most extreme were those carried out by the poet's grandnephew, Michelangelo il Giovine, for the Florentine edition of the Rime published by Giunti in 1623. This collection was the first major edition of the poems (containing 137 as opposed to the over 300 included by Girardi). It served as a model, moreover, for all of the subsequent editions until the mid-nineteenth centuryand therein lies the problem. It is certainly extreme and probably unfair to say, as Girardi does, that the grandnephew's edition "costituisce, com'è noto, uno dei piú gravi misfatti che mai editore abbia commesso ai danni di un poeta" (508). But it is nonetheless undeniable that Michelangelo il Giovine's editorial efforts-including revisions, deletions, and unjustified combinations of initially discrete poems and fragments of poems-resulted in a work that bore little resemblance to Michelangelo's original poetry. As Girardi notes, Michelangelo il Giovine's development as an editor can be traced beginnning with his first, notably faithful transcriptions of the materials that he had collected and ending with the final published versions, in which, as again Girardi notes, "di fedeltà non c’è piú nemmeno un'ombra" (494).

The Biblioteca Laurenziana in Florence contains both Michelangelo's autograph of "Vorrei voler" (in Archivio Buonarroti No. 13, f. 42) and Michelangelo il Giovine's preliminary work for his edition (in AB 15-16). The edition done by Michelangelo's grandnephew did affect the publishing of "Vorrei voler" in a very general yet crucial way; but before we consider this edition's overall effects on the poem's "fortune," it might be instructive to trace the detailed results of the grandnephew's work on the poem as his transcriptions progressed. The two tercets of Michelangelo's original read essentially as Girardi (along with Frey) gives them. ${ }^{3}$ When Michelangelo il Giovine transcribes the poem (AB 15, ff. 18-19, No. 65) the forms that we have been discussing are immediately normalized to "sua ... tua . . tua." But initially there are very few other changes, beyond orthographic ones and the underlining of "preditto" (1. 12), which perhaps suggests the grandnephew's early concerns about the reli- 
gious implications of the poem. When, toward the end of $A B 15$, Michelangelo il giovine again copies out the poem (under the notation "Spirituale"), there are many more revisions, substantive ones, both in the quatrains and in the tercets. Although the first of the tercets remains virtually unchanged, in the second the troublesome "preditto" of 1.12 is deleted and in its place a religious clarification ("tua grazia") is introduced within the sort of "soave" poetic conceit that is typical of Michelangelo il Giovine's seventeenth-century academician's taste but foreign to that of the original poet:

Manda della tua grazia un raggio puro

A quell'alma tua sposa accio ch'ella arda

Nel foco santo tuo sempre contenta

This is not the last of the grandnephew's versions of the poem, nor does the underlining of "signor" at the beginning of the first tercet augur well for the future, given the editorial adjustment in the case of "preditto" (and in those of many other words and phrases underlined by Michelangelo il Giovine throughout the manuscript as notes to himself regarding points to reconsider as he progressed with his revisions). The sonnet is also contained in $\mathrm{AB} 16$ (No. 165, toward the end of the manuscript), in a version in which the problematic gender of the poem's addressee and the urgent religious travails of its speaker are both dealt with by the editor. These two topics, sexuality and theology, are the ones that concerned the grandnephew most in his editorializing attempts to "purify" Michelangelo's works both for the sake of Michelangelo's moral reputation and for the watchful eye of the Inquisition. Here, the problems at issue are resolved by religious "paraphrase" and by capitalization of "Signor" (1. 1, a practice also followed by subsequent editors), who is now, beyond all doubt, the Christian Lord. Although significant editorial interventions are by this point apparent throughout the entire poem, for the sake of comparison we need only consider the tercets of this last version.

Tu squarcia il vel, rompi quel muro

Che con la sua durezza ne ritarda

Il sol della tua luce al mondo spenta

Manda di tua virtude un raggio puro

A quest'alma, tua sposa, accio ch'ell'arda

Nel foco del tuo amor sempre contenta

In this revision the substitution of "tua grazia," which had re- 
placed "preditto lume," in its turn gives way to "tua virtude," thus "explaining," as well as tidying up, the problematic question of the attainment of grace (a question that was central to Michelangelo's original poem and that the grandnephew attempted first to clarify and then, at last, to circumvent altogether via the notion of Christian "virtue"). At the same time, the interpretative identification of "bella sposa" with "alma" is underscored by the punctuation of apposition, and both the remarkable urgency of the original's apostrophe of 1.9 and the direct physical sensation of the poem's concluding line are smoothed out in the course of the grandnephew's editorial work.

The resultant losses, on the one hand, of immediacy and concreteness and, on the other, of emotional force and rhetorical complexity, are typical of Michelangelo il Giovine's labors throughout his collection; and they are no doubt two of the reasons for Girardi's critical displeasure. True, without Michelangelo il Giovine's work the poems would doubtless have remained unknown to the public for a considerably longer period. But it is also the case that one is led to wonder whether the price exacted in terms of the disfigurement of the poetry is actually worth the gain in terms of the canzoniere's publication. In any event, this question, as regards "Vorrei voler," remains strictly an academic one, since in the end this particular sonnet, with its thorny mix of religious and sexual motifs, was left out of the collection that Michelangelo il Giovine finally published in 1623. We have only a small part of the last manuscript version of the collection-that is, the version between AB 16 and the Giunti volume-but it was probably at that point that the poem was put aside. The editorial result for "Vorrei voler" (again the fruit of the grandnephew's labors) was silence. In effect this poem, which, notwithstanding Michelangelo il Giovine's decision, constitutes one of the finest sonnets of the sixteenth century in Italy or indeed in Europe as a whole, remained unknown until Cesare Guasti's landmark edition of 1863 , at which point, three hundred years after its creation, "Vorrei voler" was published for the first time.

Guasti's edition resulted from a thorough (if not always totally accurate) reading of the autographs, and it restored Michelangelo's system of adjectival forms in "Vorrei voler" and elsewhere, thereby reversing the practice of every edition of the poetry from 1623 on while providing an edition that was, generally speaking, faithful to 
what Michelangelo actually wrote. ${ }^{4}$ Michelangelo il Giovine's "sua ... tua . . . tua" thus reverted to Michelangelo's original "suo . . . tuo ... tuo." There are, of course, significant differences between Guasti's, Frey's, and Girardi's editions, some of which have to do with the disposition of the poetic materials, others with questions of dating and interpretation and with the details of transcription and the modernization of orthography. ${ }^{5}$ But in regard to the adjectival forms that we have been considering, the three major modern editions (as distinct from the majority of modern poetic anthologies and non-critical editions) are unanimous in retaining Michelangelo's adjectival forms, at least as they can be verified in the existing autographs. This editorial fidelity is, in and of itself, laudatory, since it tells us what the forms are; but it still does not tell us what we began by asking, that is, what, if anything, these forms mean.

By way of beginning an approach to this question, I should perhaps reiterate that these were, for Michelangelo, specifically poetic forms. He did not use them, except very rarely, in his other writings, whereas in his poetry he insisted on them, as is evident in his interlinear corrections of the manuscripts and even in his elaboration of his own emendations. Moreover, Michelangelo regularly adopted these forms throughout the entire period of his poetic production-or at least the period from which we have autographs of the poems, that is, from the early 1500's on.

As I noted before, one thing that these forms do not indicate, given the fact that they are systematic and not haphazard, is gender confusion. But even though this excludes one interpretative possibility, we are still left with the problem of what their import might be. It is significant that Michelangelo was not by any means the only person or even the only poet of major accomplishment to use these forms. As Nencioni notes, the system was used in Tuscany as early as the Trecento. It also appears (though not with one-hundredpercent consistency) in a fifteenth-century poem of special moment for Michelangelo, "La Nencia di Barberino," at least part of which is commonly attributed to Lorenzo de' Medici. The importance of this poem for Michelangelo is demonstrated in his own attempt to write an analogous rustic "canto" in the late teens or early twenties ("Tu ha' 'l viso piú dolce che la sapa," Girardi 20). Moreover, these adjectival forms also occur, though mixed with others, in early edi- 
tions of Poliziano's "Stanze per la giostra" and in the rustic verse of Bronzino, the sixteenth-century Florentine artist and poet. Such examples indicate the poetic use of these popular Tuscan forms, forms which recalled Michelangelo's origins-in Caprese and then Settignano and Florence-as well as Michelangelo's early exposure to humanist thought and letters in Lorenzo's court and his subsequent readings in the great Tuscan poets of the volgar lingua. The highest poetry in the vernacular remained for Michelangelo-as for Varchi, in his funeral oration-specifically Tuscan. Michelangelo's tribute to his homeland is thus embedded in his poetic language even though the great body of his most successful poems was written while he was in Rome in the self-exile to which he refers, however obliquely, in his sonnet to Dante, a line from which furnishes the epigraph to this essay.

This is not to say either that Michelangelo idealized the common populace-his poetic declamations against the uncomprehending "vulgo" are more than sufficient to counter such a claim-or that he followed Dante, Petrarca, Lorenzo, and Poliziano as a disciple. Michelangelo was simply too singular an artist, too willfully original, to become a popularizer or merely an imitator in the manner of so many of the petrarchisti of the Cinquecento. Michelangelo's nostalgia for what he continued to regard as his homeland (an attitude also suggested in the sonnet to Dante, albeit more by way of a lover's quarrel than a romantic longing) continues even in his absence from Florence and Tuscany. The forms of his poetic language signal the desires which go hand in hand with this physical and cultural absence, and they thus reaffirm on a purely formal level and in a minor key the Renaissance attitude of the individual artistic genius toward his own tradition, toward the artistic past out of which he writes in an attempt both to recapture it and to surpass it. This is an attitude that is not at all uncommon in Renaissance thought and letters. It is already thematized in Petrarca's canzoniere (in relation to Classical origins) and it is one that recurs with remarkable force in another typically "Renaissance" context-to take just one of many possible examples-that of the late American Renaissance poet Hart Crane, who strives to come to terms with the towering figure of Walt Whitman, his imposing yet difficult forebear, throughout the episodes and in the very language of his poetic masterpiece, The 
Bridge, the American epic that inaugurates our own era.

Along with the paleographic, philological, and critical aspects of this essay, there is, as may or may not have been obvious from the outset, a more general theoretical concern here. In a period like ours, in which such notions as "reader response" and "affective stylistics" evince far more active critical interest in the individual reader's personal experience of the literary artifact than they do in the establishment or even in the integrity of the original text, it seems useful to me to consider an example in which investigation of the original forms, however difficult or eccentric they may appear at first, actually leads to a fuller and more informed literary reading, one that not only refines our knowledge of the initial text but also enriches our critical and theoretical approach to that text. I am not in any way arguing against the modern editing of literary texts—indeed, I am in favor of Girardi's position on the twofold concept of "leggibilità" as regards his disagreement with Frey's editorial procedures. ${ }^{6}$ But I am advocating the combination of historical knowledge and literary scholarship that is required to keep the initial text's vitality alivealive in all its aspects, including yet also going beyond the re-creating experience of any single reader-both for us and for future audiences. My interest here, along with achieving a fuller and more accurate reading of Michelangelo's verse, has thus been to suggest some of the ways in which textual criticism and literary interpretation, rather than being completely separate or even at odds with one another, can indeed go happily and instructively hand in hand.

\section{Johns Hopkins University}

\section{NOTES}

1 The poem is found in Girardi, ed., 51, and in Frey, ed., 232. These two editions of the poem are equivalent except as regards orthography and punctuation. Girardi explains his editorial procedures in the "Nota filologica" included in his edition (481-547), where he also describes the codices in the Vatican and in Florence in which autographs and early copies of the poems are found. Page references to Girardi's edition are included in the text, as are references (in italics) to the poems as they are numbered in his edition.

2 This system, as found in early Tuscan, is discussed by Migliorini (226) and by Rohlfs (II: 120). Rohlfs points out that even in the plural these are reduced 
but stable forms (as does Girardi as well in his "Nota filologica" [535] when he explains the absence of apostrophes following them).

3 To record what Michelangelo actually wrote, I am providing the diplomatic text of the poem's tercets:

Squarcia luel cu signior rompi que lmuro

che con la suo durezza ne ritarda

i lsol della tuo luce almondo spenta

Manda lpredicto lume anno i uenturo

alla tuo bella sposa accio chio arda

ilcor senzalcun dubbio e te sol senta

4 In regard to "Vorrei voler," the major difference between Guasti's version and the autograph (and Frey's and Girardi's versions) is in the last line of the poem, which Guasti gives as "E te senz'alcun dubbio il cor sol senta" (244). This reading is undoubtedly due to Guasti's attempt to include an interlinear variant ("e cte") written above "cor" in the autograph. Both Girardi and Frey correct this reading.

5 Girardi explains his differences with Guasti's and Frey's editions in his "Nota filologica" 515-29.

6 "Nota filologica" 501-7.

\section{WORKS CITED}

ATANAGI, Dionigi. De le rime di diversi nobili poeti toscani. Venice: Ludovico Franco, 1565.

BUONARROTI, Michelangelo. Archivio Buonarroti Codice 13. Florence, Biblioteca Laurenziana.

- Il carteggio di Michelangelo. Edizione postuma di Giovanni Poggi.

Ed. Paola Barocchi and Renzo Restori. 5 vols. Florence: Sansoni/S.P.E.S., 1965-83.

. Codice Latino 3211. Vatican, Biblioteca Vaticana.

_ . I ricordi di Michelangelo. Ed. Lucilla Bardeschi Ciulich and Paola Barocchi. Florence: Sansoni, 1970.

BUONARROTI, Michelangelo il Giovine. Archivio Buonarroti Codici 15-16. Florence, Biblioteca Laurenziana.

. Rime di Michelagnolo Buonarroti, Raccolte da Michelagnolo suo nipote.

Florence: Giunti, 1623.

FREY, Carl, ed. Die Dichtungen des Michelagniolo Buonarroti. 1897; rpt.

Berlin: DeGruyter, 1964.

GIANNOTTI, Donato. Dialogi di Donato Giannotti de' giorni che Dante consumò nel cercare l' inferno e 'l purgatorio. Ed. Deoclecio Redig De Campos.

Raccolta di fonti per la storia dell'arte, 2. Florence: Sansoni, 1939.

GIRARDI, Enzo Noè, ed. Michelangiolo Buonarroti. Rime. Scrittori d'Italia, 217. Bari: Laterza, 1960.

GUASTI, Cesare, ed. Le rime di Michelangelo Buonarroti pittore, scultore, $e$ 
architetto. Florence: Le Monnier, 1863.

LUCENTE, Gregory L. "Lyric Tradition and the Desires of Absence: Rudel, Dante, and Michelangelo ('Vorrei uoler')." Canadian Review of Comparative Literature 10 (1983): 305-32.

MIGLIORINI, Bruno. Storia della lingua italiana. 4th ed. Florence: Sansoni, 1963.

NENCIONI, Giovanni. "La lingua." Michelangelo artista, pensatore, scrittore. Introd. Mario Salmi. 2 vols. Novara: De Agostini, 1965. II: 569-76.

ROHLFS, Gerhard. Grammatica storica della lingua italiana e dei suoi dialetti. Trans. Temistocle Franceschi. Rev. ed. Piccola Biblioteca Einaudi, 149. 3 vols. Turin: Einaudi, 1968.

VARCHI, Benedetto. Due lezzioni di M. Benedetto Varchi. Florence: Lorenzo Torrentino, 1549.

VASARI, Giorgio. "Michelagnolo Buonarroti." Le vite de' piú eccellenti pittori, scultori ed architettori scritte da Giorgio Vasari pittore aretino. Ed. Gaetano Milanesi. 9 vols. Le Opere di Giorgio Vasari. Florence: Sansoni, 1906. VII: $135-317,319-404$. 